\title{
Article
}

\section{Improved Filtration Technology for Pathogen Reduction in Rural Water Supplies}

\author{
Valentine Tellen $^{1, *}$, George Nkeng ${ }^{1,2}$ and Steven Dentel ${ }^{3}$ \\ 1 University of Buea, P.O. Box 63, South West Region 273, Cameroon \\ 2 National Advanced School of Public Works (ENSTP) Yaoundé, B.P. 510, Yaoundé, Cameroon; \\ E-Mail: gnkeng@yahoo.com \\ 3 Department of Civil and Environmental Engineering, University of Delaware, Newark, DE 19716, \\ USA; E-Mail: dentel@UDel.edu \\ * Author to whom correspondence should be addressed; E-Mail: tvasong@ yahoo.com; \\ Tel: +23-7-7791-0935; Fax: +23-7-2222-1816.
}

Received: 30 April 2010; in revised form: 20 May 2010 / Accepted: 10 June 2010 /

Published: 18 June 2010

\begin{abstract}
Intermittent bio-sand filtration (BSF) is a low-cost process for improving water quality in rural households. This study addresses its two drawbacks: flow limitations requiring excessive waiting, and inadequate purification when high flows are imposed. Two modifications were examined: increasing the sand's effective size, and adding zero-valent iron (ZVI) into the media as a disinfectant. After 65 days, percent reductions in total coliform, fecal coliform, and fecal streptococci averaged $98.9 \%$ for traditional BSF and $99 \%$ for the improved BSF. Both modifications showed statistically significant improvements. Increased sand size and ZVI addition can counter the drawbacks of traditional BSF.
\end{abstract}

Keywords: bio-sand filtration; zero-valent iron; microbial reductions; household drinking water treatment

\section{List of Acronyms and Abbreviations}

AFNOR Standard Association Francaise pour la Normalisation (French National Standards Institute)

BSF Bio-sand Filter 


$\begin{array}{ll}\text { CAWST } & \text { Center for Affordable Water and Sanitation Technology } \\ \text { DBPs } & \text { Disinfectant by-products } \\ \text { FC } & \text { Fecal Coliform } \\ \text { FS } & \text { Fecal Streptococci } \\ \text { Geosmin } & \text { Trans-1, 10-dimethyl-trans-9-decalol } \\ \text { MIB } & \text { 2-methylisoborneol } \\ \text { MS-2 } & \text { A type of bacteriophage } \\ \text { NOM } & \text { Natural Organic Matter } \\ \text { NTU } & \text { Nephelometric Turbidity Unit } \\ \text { OX174 } & \text { A type of bacteriophage } \\ \text { SSF } & \text { Slow Sand Filter } \\ \text { TC } & \text { Total Coliform } \\ \text { U.S. EPA } & \text { United States Environmental Protection Agency } \\ \text { UDaily archive } & \text { University of Delaware Daily archive } \\ \text { UN } & \text { United Nations } \\ \text { WEDC } & \text { Water Engineering Development Center } \\ \text { WHO } & \text { World Health Organization } \\ \text { ZVI } & \text { Zero-valent iron }\end{array}$

\section{Introduction}

The use of contaminated waters for drinking and bathing is one of the principal pathways for infection by diseases that kill millions and sicken more than a billion people each year [1]. There is a need for a sustainable, cost-effective, and reliable point-of-use (POU) water treatment to provide safe drinking water in the rural communities of developed and developing countries. Technologies commonly employed in the developing world are typically too expensive, too complex to be locally maintained and repaired, and incompatible with local customs and beliefs.

Recently, Sobsey et al. [2] compared five different household water treatment technologies, according to criteria for performance and sustainability, and found that bio-sand filters (BSF) and ceramics are the most effective household water treatment technologies. Interestingly, over 500,000 people in developing countries currently use BSF [3]. However, the BSF is not without its drawbacks. The focus of this research is geared towards improvement of the household bio-sand filter.

\subsection{Background}

Biofiltration encompasses all forms of water filtration that include a biologically mediated treatment component, and this includes a wide variety of applications, designs, media, filtration rates, and water treatment capabilities. This review focuses particularly upon intermittent slow sand filtration (SSF) or bio-sand filtration (BSF), a "low technology" water treatment process that has a long history of successful international application (see Figure 1). The performance of BSF is controlled by an ecosystem of living organisms (biolayer or schmudzdecke) whose activities are affected by the raw water quality, and in particular, by the temperature. The quality of the treated water and the 
maintenance requirements for the system depend on selected variables like sand size, flow rate, and sand bed depth.

The sand used is characterized by its effective size (ES or $\mathrm{d}_{10}$ ) and uniformity coefficient (UC or $\mathrm{d}_{60} / \mathrm{d}_{10}$ ). The recommendations for ES vary between $0.15 \mathrm{~mm}$ and $0.40 \mathrm{~mm}$ [4]. The UC should be between 1.7 and 3.0, but preferably not greater than 2.7 [5]. The sand bed depth can be up to $1.4 \mathrm{~m}$ and a minimum depth of $40 \mathrm{~cm}$. The conventional flow rate is $0.1 \mathrm{~m} / \mathrm{h}$ or $0.6 \mathrm{~L} / \mathrm{m} \mathrm{[4]}$. However, it is possible to increase the flow rate considerably if effective pretreatment is given, and if an effective disinfection stage follows the filtration [5]. The National Environmental Engineering Research Institute [6] in India used flow rates of $0.1,0.2$ and $0.3 \mathrm{~m} / \mathrm{h}$ and found no significant difference in fecal coliform reduction. Huisman and Wood [7] reported the use of higher filtration rates $(0.25$ and $0.45 \mathrm{~m} / \mathrm{h}$ ) without any marked difference in effluent quality.

Figure 1. Cross-sectional diagram of a traditional concrete intermittent bio-sand filter (BSF). Such a filter was used in these experiments (Modified from CAWST [8]). The zero-valent iron (ZVI) layer is only included in filter F3.

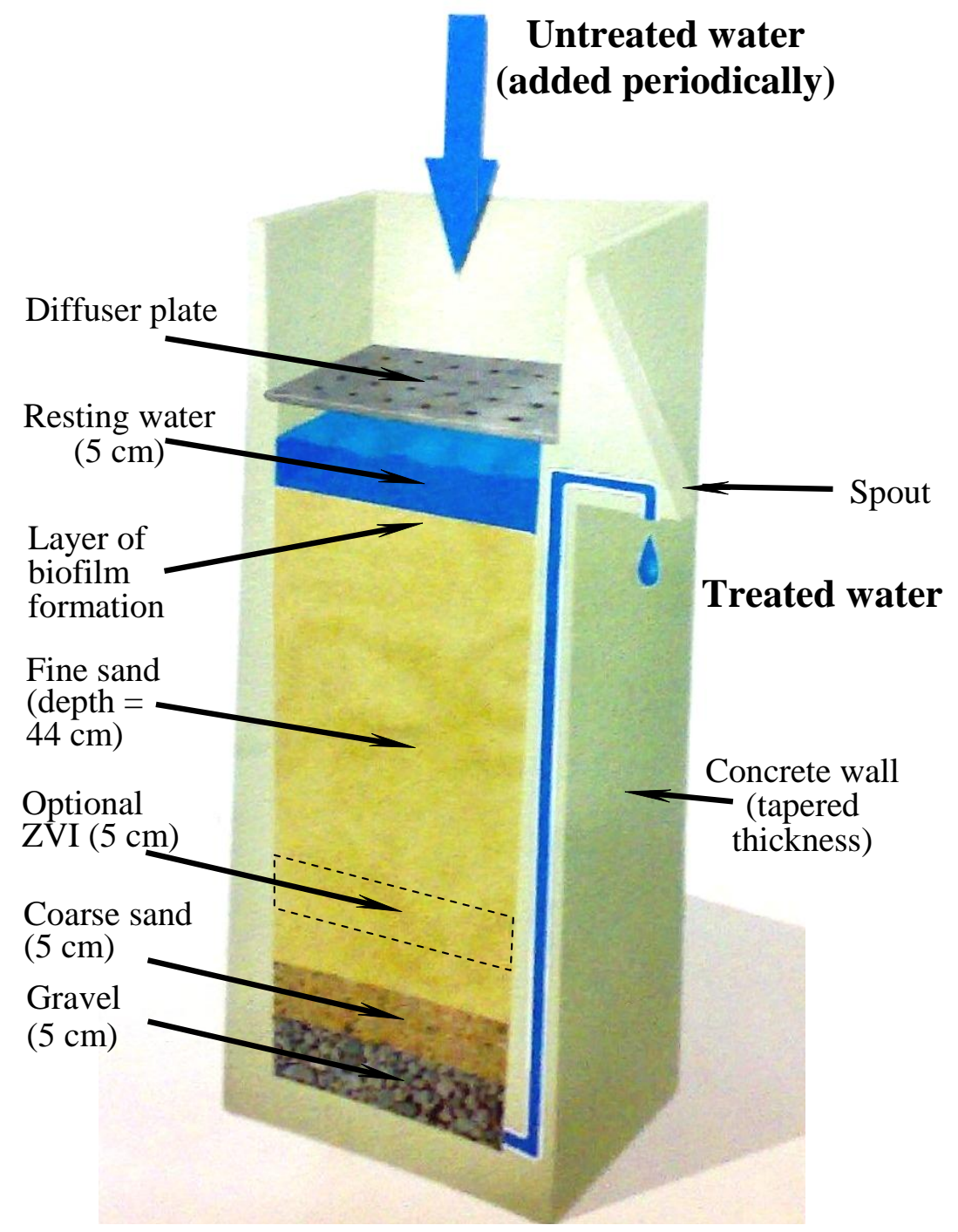


Additionally, BSF, due to its relative simplicity of design, basic maintenance procedures, and low labor costs, has often been considered suitable for smaller, less developed communities or those with less knowledge, skills, or access to higher technologies. However, SSF has also been applied for the treatment of water at large-scale process plants in highly developed countries. SSF, as with other water treatment technologies (individually or in treatment trains as operational systems), has distinguishable capacities for the improvement of water quality. These capacities have been well described and are detailed in numerous published papers, reviews, manuals, and texts. In fact, Huisman and Wood [7] state "No other single water treatment process can improve the physical, chemical, and bacteriological quality of surface water better than bio-sand filtration."

Nonetheless, two drawbacks to the household BSF can be noted:

1. The flow rate through the sand decreases with usage, and this limit to water availability may lead to the application of excessive flows or use of other (untreated) sources of water.

2. Purification may be inadequate — especially with virus removal—when high flows or frequent loadings are imposed [9-13].

\subsection{Research Objectives}

This research assessed two improvements to the household bio-sand filter to alleviate the two drawbacks cited above:

- Increase in sand grain size. The greater pore size would be expected to increase initial flow rates and, possibly, flow rates even as the bio-layer develops.

- Addition of zero-valent iron (ZVI) as a supplemental filter medium. This material, locally available as iron filings, has been shown $[14,15]$ to have a biocidal effect on pathogens.

These modifications were intended to improve the quality of water provided to users and to reduce unnecessary waits for production of treated water. The filter performance was to be assessed based on the removal of total coliform (TC), fecal coliform (FC), and fecal streptococci (FS). In addition, turbidity, natural organic matter, flow rate, odor, and dissolved iron were closely examined.

\section{Materials and Methods}

\subsection{Filter Characteristics}

The approach was to employ BSF units that were exactly as constructed and used in households, but within a controlled laboratory setting. Accordingly, two concrete filters were constructed inside the hydrology laboratory of the National Advanced School of Public Works in Yaoundé. The room temperature range was $23-27{ }^{\circ} \mathrm{C}$. Filters were of the standard $1 \mathrm{~m}$ height and $0.3 \mathrm{~m}$ side dimensions. The two filters were used in three configurations F1, F2, and F3, with media characteristics shown in Table 1.

Filter configuration F2 acted as the control, with the standard media size of $0.15 \mathrm{~mm}$. Configuration F1 tested the effects of increased media size $(0.3 \mathrm{~mm}) . \mathrm{F} 3$ tested the efficacy of both an increased media size and the addition of ZVI as a layer around the lower part of its sand media. 
Table 1. Characteristics of filter challenge experiments.

\begin{tabular}{clc}
\hline Filter Configuration & Filter Media (see Figure 1) & ${ }^{\mathbf{1}} \mathbf{E S}$ or $\mathbf{D}_{\mathbf{1 0}}$ \\
\hline F1 & River sand & $0.3 \mathrm{~mm}$ \\
\hline F2 & Crushed granite gravel & $0.15 \mathrm{~mm}$ \\
\hline F3 & River sand + ZVI $(0.5 \mathrm{~kg})$ & $0.3 \mathrm{~mm}$ \\
\hline
\end{tabular}

${ }^{1} \mathrm{ES}$ or $\mathrm{D}_{10}$ is the effective size of sand.

\subsection{Filter Construction and Design}

Filters were constructed using a steel mold according to the specifications of the Center for Affordable Water and Sanitation Technology (CAWST), and generously loaned by the Life and Water Development Group in Cameroon. Materials required for each filter were three head pans of gravel, 1.5 wheelbarrows of sand, 1 bag of cement, and sufficient water to provide concrete mix consistency. Each filter also required $1.5 \mathrm{~m}$ of $0.6 \mathrm{~mm}$ PVC pipe, an aluminum diffuser plate, and a wooden cover lid (not shown in Figure 1).

Following the quantities mentioned above, gravel, sand, cement, and water were mixed together to form a mortar, which was then loaded into a steel mold (Plate 1). After 24 hours, the mold was removed and the empty concrete filter was obtained (Plate 2). The mold and the filters were fabricated, following the CAWST manual [8], and as shown in Figure 1.

\subsection{Media and Filter Preparation}

The steps used, in the construction, media preparation, and operation of the concrete intermittent bio-sand filters, are represented in plates, as shown in Figure 2. River sand was selectively sieved, using a set of sieves for sand analysis, to obtain an $\mathrm{ES}=0.3 \mathrm{~mm}$ (i.e., $\mathrm{D}_{10}=0.3 \mathrm{~mm}$ ) and a UC of 1.7 (Plate 3). The sand was washed (Plate 5) and then loaded consecutively into F1 and F3 (Plate 7), but there was a column of ZVI mixed with sand in F3 (Figure 1). The crushed rock was sieved, following the Standard International Field procedure for BSF, to obtain an ES of $0.15 \mathrm{~mm}$, with a UC of 2, and loaded in F2 (Plate 4). The loading of the filter constituents was in the sequence of: $5 \mathrm{~cm}$ gravel $(6-12 \mathrm{~mm}), 5 \mathrm{~cm}$ coarse sand $(2.5-4 \mathrm{~mm})$ (Plate 6$)$, then $44 \mathrm{~cm}$ sand media $(0.15 \mathrm{~mm}$ for F2, $0.3 \mathrm{~mm}$ for F1 and F3). The depth of ZVI in F3 was $5 \mathrm{~cm}$. Also, water was present inside the filter before loading to avoid any occurrence of air spaces. Otherwise, there would be anaerobic conditions and abnormalities in the flow of water through the sand. Turbid water was poured into the BSF and the filtrate appeared to be clear (Plate 8).

An aluminum diffuser plate was then placed on the lip of the filter to avoid disturbance of the top layer of sand during water loading of the filter (Plate 10). The gravel (Plate 6) provided a support that prevented the clogging of the PVC pipe by sand, keeping the opening of the filter bottom free for the flow of water out of the filter. It has been shown that crushed rock is a better media type compared to sand, and Rao [16] found that crushed rock media with an ES of $0.47 \mathrm{~mm}$ recorded the best results in terms of bacteria removal, turbidity removal, and length of filter runs, when compared to sand media of same ES. Unfortunately, crushed granite gravel is uncommon and it is expensive to produce in Cameroon and most developing countries. Moreover, the idea here was to exploit the traditional BSF 
to the best performance possible and to compare to that of the improved BSF made from locally available river sand.

Figure 2. Plates showing the steps used in the construction, media preparation, and operation of the concrete intermittent bio-sand filters.
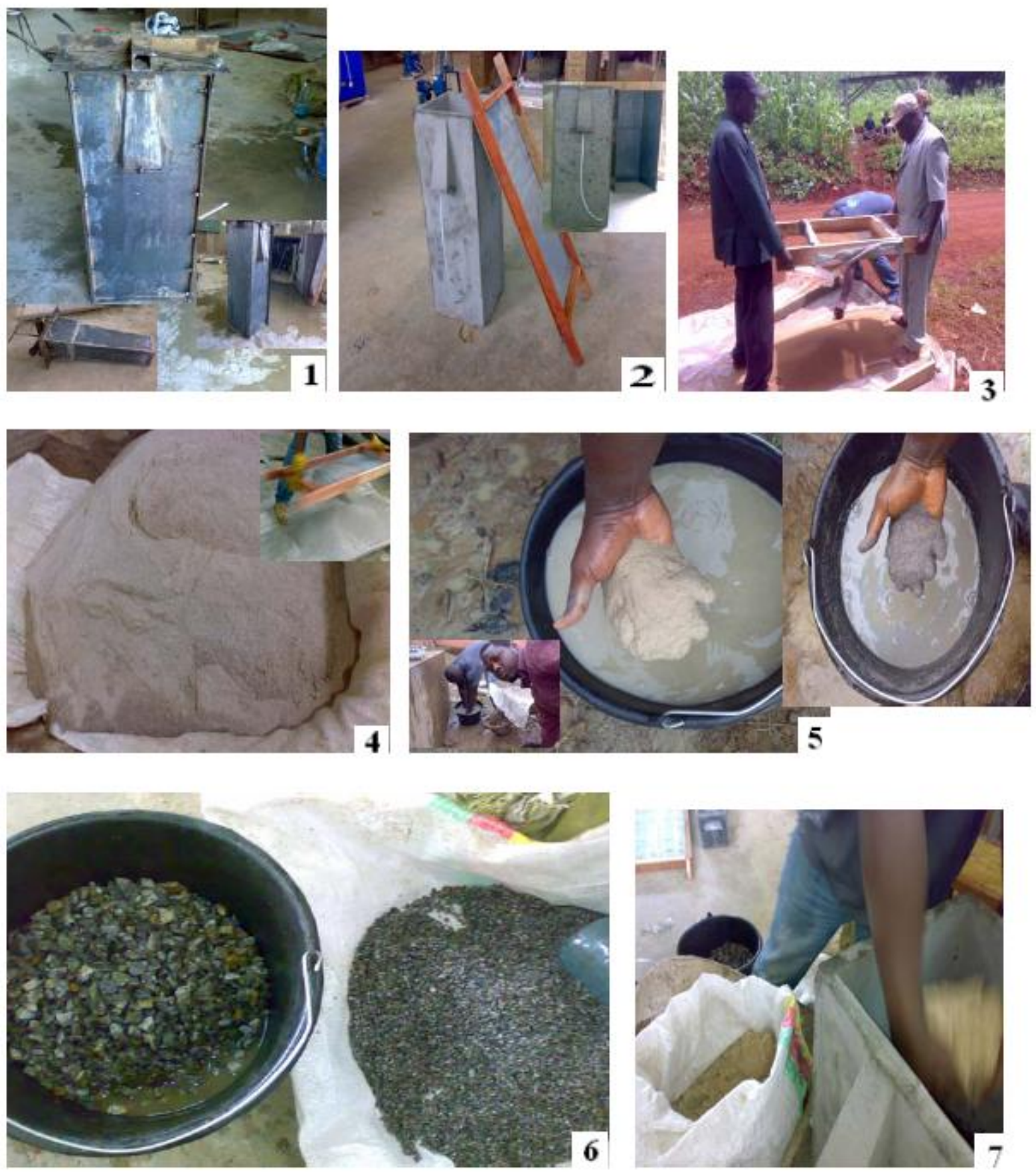
Figure 2. Cont.
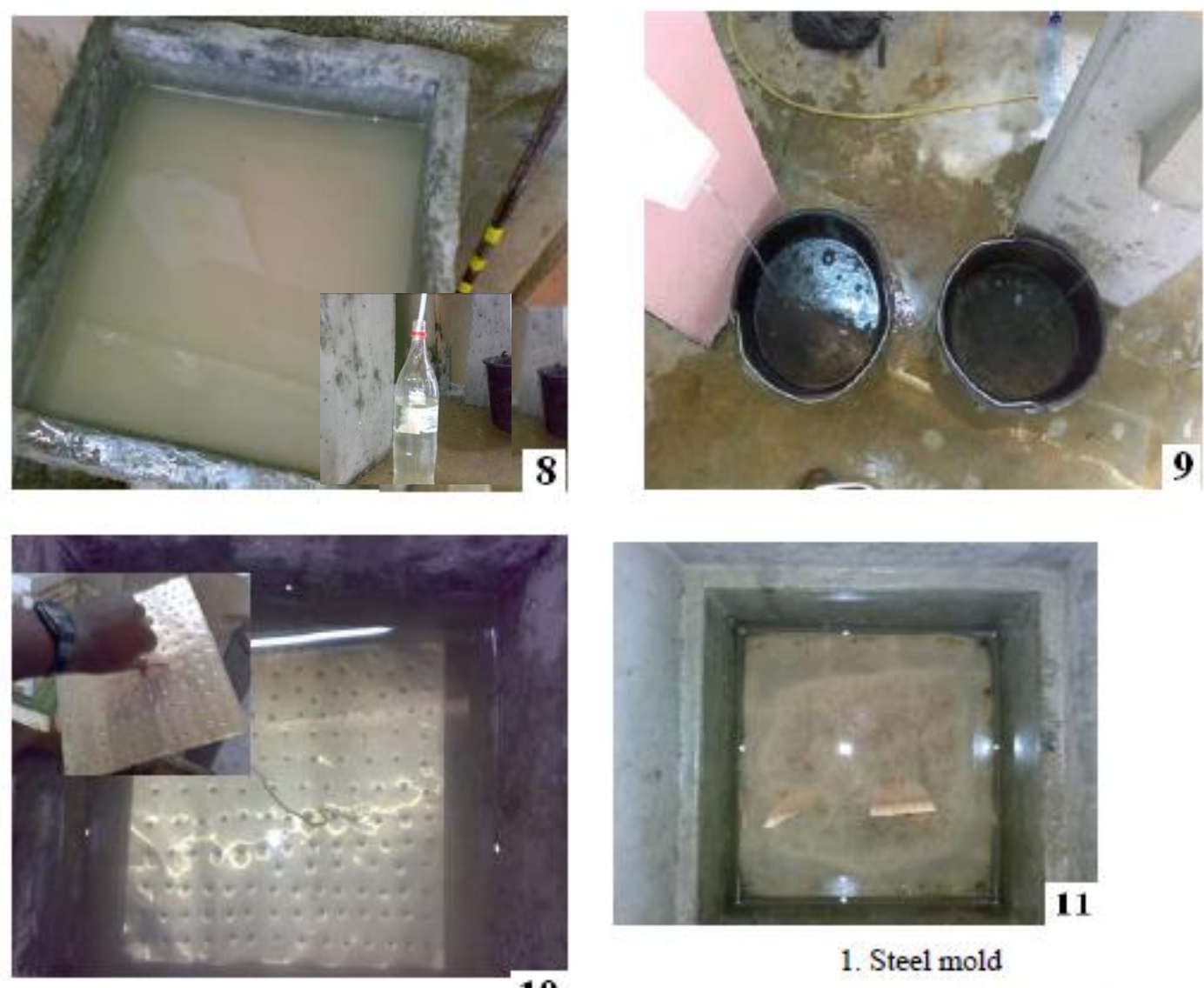

1. Steel mold

10

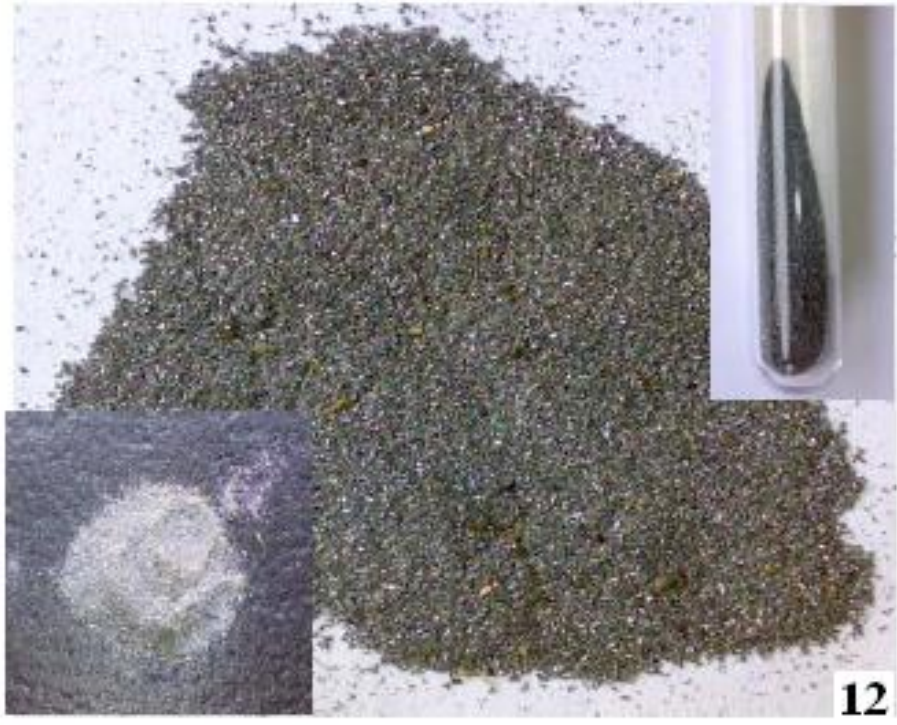

2. Empty concrete boxes

3. Sand sieving

4. Sieved crushed rock

5. Washing the sieved sand

6. Pumice and coarse sand

7. Loading of concrete box.

8. Turbid water filed in the BSF and results in clear filtered water.

\section{Operating BSF}

10. Aluminum Metal diffusing plate placed on lip of BSF

11. Resting water above sand during paused period

12. Zero-valent iron (ZVI)

Following a $20 \mathrm{~L}$ water charge, the initial flow rates in each filter experiment were 2.1, 1.2, and $1.9 \mathrm{~L} / \mathrm{m}$ for $\mathrm{F} 1, \mathrm{~F} 2$, and F3 respectively. The sand bed depths for all three filters were kept constant at $44 \mathrm{~cm}$, while the water head levels were also kept constant, with $5 \mathrm{~cm}$ (2”) of head during the pause period (Plate 11). The porosity was determined using the cubic lattice approach. It was assumed that sand is well packed and has a face-centered cubic lattice alignment. The three-dimensional structure of $\mathrm{F} 2$ has a packing density of $74 \%$, resulting in a void fraction (or 
porosity) of $26 \%$ or 0.26 , while $\mathrm{F} 1$ and $\mathrm{F} 3$ have a packing density of $70 \%$, resulting in a porosity of 0.3 . The two filters used for the three different experiments are shown in Plate 9. Based on the filter characteristics, as described in Table 1 above, two experiments used these filters with the configurations F1 and F2. Configuration F1 was then replaced with F3 by emptying and replacing the filter contents, as detailed in Table 1.

\section{Zero-Valent Iron (ZVI)}

The ZVI (iron filings) used for this study was composed of commercial iron particles obtained from a peerless metal powder and abrasive workshop, where cutlasses and knifes are sharpened, and iron materials are made smooth (Plate 12). The iron filings were washed with tap water until the waste water, which was initially dark in color, showed no further decrease in clarity.

\subsection{Experimental Design}

Three filtration experiments, each with a duration of 65 days, were conducted consecutively. Two comparisons of configurations F1 and F2 were followed by an experiment comparing F2 to F3, to determine the efficacies of the three bio-sand filters in reducing the concentration of fecal coliform (FC), total coliform (TC), and fecal sreptococci (FS), and to explore the effects of daily water charge on microbial reduction. In addition, turbidity and natural organic matter (NOM) were monitored. The filters were charged with raw water drawn daily from a well, with the water containing sufficient levels of challenge microorganisms to obviate the need for seeding.

\subsection{Sample Collection}

Sample bottles of volumes of $1 \mathrm{~L}$ each, provided by the Environment and Hygiene Laboratory at the Centre Pasteur du Cameroon, Yaoundé, were used to collect water samples from each filter after 14, 19 and 62 days, respectively, for microbial analysis. These samples included the raw water and the filtered water from both filters.

The time of sample collection and transportation to the lab was less than 1 hour, while at room temperature. Elliott et al. [17] demonstrated minimal mean die-off rates for challenge microorganisms after overnight storage at room temperature. Thus, the effects of time and temperature on microbial survival were regarded as negligible in this study.

\subsection{Odor Management}

After the fifth week, there were odor problems produced from the F2 effluent. Thus, all three filters were cleaned by pouring some water on the top of the sand bed and gently swirling the upper layer of the sand using the hand, such that the suspended particles mixed with the water, which was then removed using a cup.

\subsection{Microbial Analysis of Water Samples}

Raw water was collected from a well, used for drinking, and other domestic purpose. Total coliform, fecal coliform, and fecal streptococci in water were not seeded, but occurred naturally and were 
quantified using the membrane filtration technique. The medium used were SLANETZ \& Tergitol 7 , at $37{ }^{\circ} \mathrm{C}$ for $24 \mathrm{~h}$, and at $44{ }^{\circ} \mathrm{C} \pm 0.5{ }^{\circ} \mathrm{C}$ for TC and FC, respectively, and ENTEROSEL agar at $37{ }^{\circ} \mathrm{C}$ for $48 \mathrm{~h}$ for FS. The reductions, in pathogen indicator concentrations by passage of raw water through the three BSFs, were calculated in percentages.

\subsection{Physico-Chemical Analysis of Water Samples}

Turbidity and $\mathrm{pH}$ were measured using a conventional turbidimeter (Model 2100n, Hach, Loveland, $\mathrm{CO}, \mathrm{USA}$ ) and $\mathrm{pH}$ electrode, respectively. The amount of natural organic matter (NOM) in each sample was measured by the oxidizability of sample water. Oxidizability was determined by reaction with hot oxidized potassium permanganate $\left(\mathrm{KMnO}_{4}\right)$. The amount of dissolved iron $\left(\mathrm{Fe}^{3+}\right.$ or $\left.\mathrm{Fe}^{2+}\right)$ present in the water sample from F3 was monitored over the course of the filtration experiment, using a spectrophotometer, since iron becomes oxidized when in contact with water.

Analyses were done at the Environment and Hygiene Laboratory at the Centre Pasteur du Cameroon, Yaoundé. Based on the observed parameters, the results were compared to the chemical and microbiological criteria of the French Norm AFNOR, which is used as Cameroon's water norm for water destined for human consumption. This norm has limits, which are similar to WHO guidelines for drinking-water quality [18].

\subsection{Data Analysis}

Data from microbial analysis were subjected to analysis of variance ratio (ANOVA) and comparisons made between treatment means to see if there were significant differences between treatments. In order to investigate this further, Tukey's post hoc test was employed to determine which treatments differed significantly from the rest. Also, bi-variable graphical displays were use to analyze turbidity, flow rate, and microbial removal. The analyses were done using Minitab 15 and Microsoft Office Excel 2007.

\section{Results and Discussion}

Results are presented in six subsections: microbial reduction; NOM removal; water chemistry effects; head-loss development over BSF operating time; turbidity removal; taste and odor removal; and finally, effect of media size. Results from separate filtration runs have been consolidated to facilitate comparisons. In light of the interpretation, the section then discusses the extent to which the improved BSF complements the traditional BSF for increasing rate of flow, while assuring pathogen removal.

\subsection{Microbial Reduction}

Table 2 shows the concentration of pathogen indicators that were measured during the course of the filtration experiment. 
Table 2. Concentration of pathogen indicators measured from water samples collected during the course of filter experiments.

\begin{tabular}{|c|c|c|c|c|}
\hline & \multicolumn{5}{|c|}{$\begin{array}{c}\text { Concentration of Pathogen indicators } \\
\text { (Colony Forming Units per 100 mL) }\end{array}$} \\
\hline \multirow{2}{*}{ Pathogens } & \multicolumn{5}{|c|}{ Week 2 } \\
\cline { 2 - 5 } & Raw Water & F1 & F2 & F3 \\
\hline TC & $>100$ & $>100$ & 10 & 0 \\
\hline FC & $>100$ & $>100$ & 10 & 0 \\
\hline FS & 100 & 80 & 10 & 0 \\
\hline \multicolumn{5}{|c|}{ Week 4 } \\
\hline TC & $>100$ & 100 & 3 & 0 \\
\hline FC & $>100$ & 100 & 3 & 0 \\
\hline FS & 100 & 50 & 0 & 0 \\
\hline & $>100$ & 80 & 0 & 0 \\
\hline TC & $>100$ & 80 & 0 & 0 \\
\hline FC & 100 & 30 & 0 & 0 \\
\hline FS & \multicolumn{5}{|c|}{ Week 9 } \\
\hline
\end{tabular}

\subsubsection{Total and Fecal Coliforms}

The microbial counts and percent reduction of total and fecal coliforms (Tables 2, 3a, and 3b) were consistent with each other. The $p$ value for the ANOVA ( $\mathrm{p}=0.001$, which is $<0.05)$ indicates that the treatment means differed. Because there was a trend of increased pathogen indicator reduction with time, the average values are only meaningful in a qualitative sense. Although the $95 \%$ confidence intervals $(\mathrm{CI})$ do overlap, percentage reduction in TC from $\mathrm{F} 3$ appears to be greater than those from the other two filters.

Tukey's post hoc test was used for more rigorous statistical comparisons. At a 95\% confidence level, comparison of averages for F1 and F2, and F1 and F3, differed significantly in pathogen indicator levels, but F2 and F3 did not. This shows that either the ZVI inclusion or the increased media size improved performance over the conventional BSF, but that neither modification was significantly superior to the other.

\subsubsection{Fecal Streptococci}

The percent reduction of fecal streptococci is shown in Table $3 \mathrm{c}$ and the $p$ value for the ANOVA $(p=0.000)$ indicates that the averages of the groups will differ from each other at a $95 \%$ confidence interval. Statistical conclusions are the same for coliforms: F2 was not significantly different from F3, while F1 differed significantly from F2 and F3.

The trend in F1 and F2 filtration experiments is towards increased TC, and FC and FS percent reductions over time (Tables $3 a$ and $3 b$ ). This suggests the impact of ripening, caused by maturation of biofilm, while in the F3 experiment, the results demonstrate the impact of ZVI (a disinfectant) through high percentage removal of FC, TC, and FS throughout the filtration experiment. Although percent reductions in FS were equal for F2 and F3, the percent reductions in TC and FC were lowest for F1, intermediate for F2, and highest for F3 experiments. 
Table 3. Percent reductions in (a) Total Coliform, (b) Fecal Coliform, and (c) Fecal Streptococci, over the course of three filter experiments.

\begin{tabular}{|c|c|c|c|}
\hline Time (days) & \multicolumn{3}{|c|}{ Percent Reduction of Total Coliform (\%) } \\
\hline & F1 & F2 & F3 \\
\hline 14 & 0 & 98.88 & 99 \\
\hline 29 & 0 & 98.97 & 99 \\
\hline 62 & 95 & 99 & 99 \\
\hline Average & 31.7 & 98.9 & 99 \\
\hline
\end{tabular}

(a)

\begin{tabular}{|c|c|c|c|}
\hline Time (days) & \multicolumn{3}{|c|}{ Percent (\%) Reduction of Fecal Coliform } \\
\hline & F1 & F2 & F3 \\
\hline 14 & 0 & 98.88 & 99 \\
\hline 29 & 0 & 98.97 & 99 \\
\hline 62 & 95 & 99 & 99 \\
\hline Average & 31.7 & 98.9 & 99 \\
\hline
\end{tabular}

(b)

\begin{tabular}{|c|c|c|c|}
\hline Time (days) & \multicolumn{3}{|c|}{ Percent (\%) Reduction Of Fecal Streptococci } \\
\hline & F1 & F2 & F3 \\
\hline 14 & 95 & 98.88 & 99 \\
\hline 29 & 98 & 99 & 99 \\
\hline 62 & 98.57 & 99 & 99 \\
\hline Average & 97.2 & 99 & 99 \\
\hline
\end{tabular}

(c)

Also, the results suggest that biological activity may play a major function in $\mathrm{F} 2$; the percent reductions of FC and TC increased over time (suggesting biofilm ripening). This is expected, as a smaller sand size will have a larger total surface area available for biofilm growth, and therefore, more biofilm can be in contact with the raw water. Nam et al. [19] demonstrated that finer sand beds had close to three times the biofilm surface area per unit sand area compared to coarser sand beds. F1 had a larger sand size, hence larger interstices between the sand grains, smaller surface area, and higher flow rate. This gave rise to less adsorption and less total surface area for biofilm to grow on. In fact, the 95\% reductions in FC and TC after the eighth week suggests less biofilm formation, which may account for the resulting poor pathogen indicator removal in F1. From this perspective, it is reasonable to suggest that pathogen indicator removal was achieved primarily through biofilm formation in F2 but to a lesser extent in F1 and F3. The F3 case show high values from the start of the filtration experiment and it is suggested to be primarily due to the ZVI in this filter, which is suggested to have a biocidal effect on pathogens.

Recent research by Elliott et al. [3] on reductions of $E$. coli, echovirus type 12, and bacteriophages in a bio-sand filter show that filter performance depended on the ripening time (time required for biolayer development) and on the volume of water poured into the filter daily. After 30 days of ripening time, the bio-sand filter reduced E. coli by almost $99 \%$ on average. Virus removal by the bio-sand filter differed greatly, depending on the specific viral agent. Of the two different types of 
viruses tested, the bio-sand filter reduced echovirus 12 by more than $99 \%$ on average; however, the filter reduced bacteriophage (MS2 and PRD-1) concentrations by $70 \%$ on average. The paper identified the pause period for the filter as an important operating parameter, with implications on the recommended quantity of water per day and the frequency of use. Their results confirm the challenge, to the traditional BSF, of the limited volume of water that can be poured into the filter daily.

This research is the first demonstration of pathogen removal from contaminated water by a household bio-sand filtration incorporated with ZVI as a disinfectant. Changha et al. [14] suggested that the reaction of $\mathrm{Fe}$ (II) with intracellular oxygen or hydrogen peroxide may induce oxidative stress by producing reactive oxygen species that cause cell lyses of bacteria, such as E. coli. It was said that the bactericidal effect of ZVI nanoparticles was a unique property which was not observed in other types of iron. The result suggests that pathogen removal in the improved filter experiment was achieved due to the biocidal effect of ZVI, while that of traditional BSF was achieved due to the formation of a biofilm in the upper layer of the sand bed.

Tables $3 \mathrm{a}$ and $3 \mathrm{~b}$ shows that on average, the reduction achieved by F3 in FC and TC is $99 \%$. This shows the effectiveness of ZVI as a disinfectant in a household BSF, and also as a supplemental medium to compensate for the inadequate pathogen removal as in F1, which had the larger media ES. Table 3c shows that the average percentage reductions in FS for F2 and F3 were not significantly different (99\%), but less for F1, compared to the other two. Although FS is suggested to be removed primarily by straining, and the effect of capture in a traditional SSF, ZVI evidently adds other mechanisms, plausibly involving adsorption and inactivation for removal.

Chiu [20] noted that by using elemental iron in a filtration process, viral agents from drinking water were removed at very high efficiencies. Virus removal was $99.99 \%$ after 20 minutes and eventually exceeded $99.999 \%$. The zero-valent iron (Fe) used in this process is inexpensive and widely available as a by-product of iron and steel production. Viruses were speculated to be either chemically inactivated or irreversibly adsorbed to the iron [20]. Plausibly, the improved BSF (F3) technology could provide $99.999 \%$ virus removal, unattainable with the traditional BSFs (F1 and F2).

Murray and Laband [21] applied kinetic theory to data obtained from sequential extractions of adsorbed virus and suggested that the inactivation observed was due to the physical disruption of virions. He also suspected that the van der Waals interactions between solid surfaces and virus induced spontaneous virion disassembly. Also, You et al. [15] reported that viral removal by zero-valent iron was over $4 \log _{10}$ in an initial pulse test and over $5 \log _{10}$ in a second pulse test. They assumed that the improved efficiency was due to continuous formation of new iron (oxyhydr)oxides, which served as virus adsorption sites.

In addition, both the magnetite and hematite present in the iron have been shown to absorb a variety of viruses. Moore et al. [22] analyzed the adsorption of poliovirus type 2 by 34 well defined soils and minerals and discovered that magnetite sand and hematite, which were predominantly oxides of iron, were the most effective adsorbents. In a recent study using goethite-coated sand [23], they further showed that $90 \%$ of MS-2 and $95 \%$ of ØX174 were removed, and that the removal was due mainly to inactivation, rather than reversible adsorption. An additional 1-to- $2 \log _{10}$ removal was observed and was most likely due to the formation of new iron oxides (i.e., new adsorption sites) resulting from the corrosion of ZVI during a 10 day period. Although removal via filtration by sand alone in the F3 experiment could not be completely excluded, it was probably negligible, since the iron column had a 
higher porosity than the sand column, where removal was minimal (as in F1). Additionally, no pressure build-up or flow rate reduction was observed over this period.

Therefore, it is reasonable to suggest that the biocidal effects of ZVI on TC, FC, and FS removal and the inactivation within the improved BSF (F3), may account for the $99 \%$ reduction of the challenge microorganisms at the beginning of the F3 experiment, suggesting that the improved filter could account for even better results as the biofilm matures with time. Therefore, it can be suggested that straining, the effect of capture due to change in transport efficiency, and to some extent biofilm formation, as seen in F1, may account for the 99\% reduction in the challenge microorganisms at the end of the F3 experiment. In contrast, the effect of straining and capture due to change in transport efficiency may account for $98.88 \%$ reduction for traditional BSF (F2) at the start of the filtration experiment, while in addition, biofilm formation may account for a $99 \%$ reduction at the end of the experiment. These suggested factors, which are involved in the removal of pathogen indicators from the traditional BSF (F2) and the improved BSF (F3), are summarized in Table 4.

Table 4. Suggested factors involved in pathogen removal.

\begin{tabular}{|c|c|c|c|c|}
\hline & \multicolumn{2}{|c|}{ Traditional BSF (F2) } & \multicolumn{2}{c|}{ Improved BSF (F3) } \\
\hline Days & Factor & $\begin{array}{c}\text { Pathogen indicator } \\
\text { removal }\end{array}$ & $\begin{array}{c}\text { Fathogen indicator } \\
\text { removal }\end{array}$ \\
\hline \multirow{2}{*}{$<14$} & $\begin{array}{c}\text {-Straining } \\
\text {-Capture efficiency }\end{array}$ & $<98.88 \%$ & $\begin{array}{c}\text {-ZVI biocidal effects } \\
\text {-Capture efficiency } \\
\text {-Straining }\end{array}$ & $99 \%$ \\
\hline$>14$ & $\begin{array}{c}\text {-All factors for }<14 \text { days } \\
\text {-Biofilm }\end{array}$ & $98-99 \%$ & $\begin{array}{c}\text {-All factors for }<14 \text { days } \\
\text {-Biofilm }\end{array}$ & $99 \%$ \\
\hline
\end{tabular}

\subsection{Natural Organic Matter}

Slow sand filtration removes NOM due to both biodegradation and adsorption [24,25]. Table 5 and Figure 3 present NOM levels, showing that during the first two weeks, the NOM in the effluent from F3 was less, but increased with time. Although NOM is undoubtedly required for bacterial growth within the biolayer, levels in treated water exceeded those in the raw water in some cases. This only occurred after 28 and 62 days of treatment, and a cleaning of the BSFs during the fifth week decreased NOM levels. This suggests that sloughing from the mature biolayer was responsible for the increased NOM in treated water.

Table 5. Natural organic matter levels as measured by permanganate oxidation.

\begin{tabular}{|c|c|c|c|c|c|}
\hline \multicolumn{7}{|c|}{ NOM (mg/L) } \\
\hline Days & Raw Water & F1 & F2 & F3 & AFNOR/WHO Limits \\
\hline Day 14 & 2.9 & 1.6 & 0.9 & 0.6 & $<5$ \\
\hline Day 28 & 2.5 & 2.9 & 6.2 & 3.3 & $<5$ \\
\hline Day 62 & 2.3 & 2.4 & 3.2 & 1.8 & $<5$ \\
\hline
\end{tabular}


Figure 3. Natural organic matter levels as measured by permanganate oxidation.

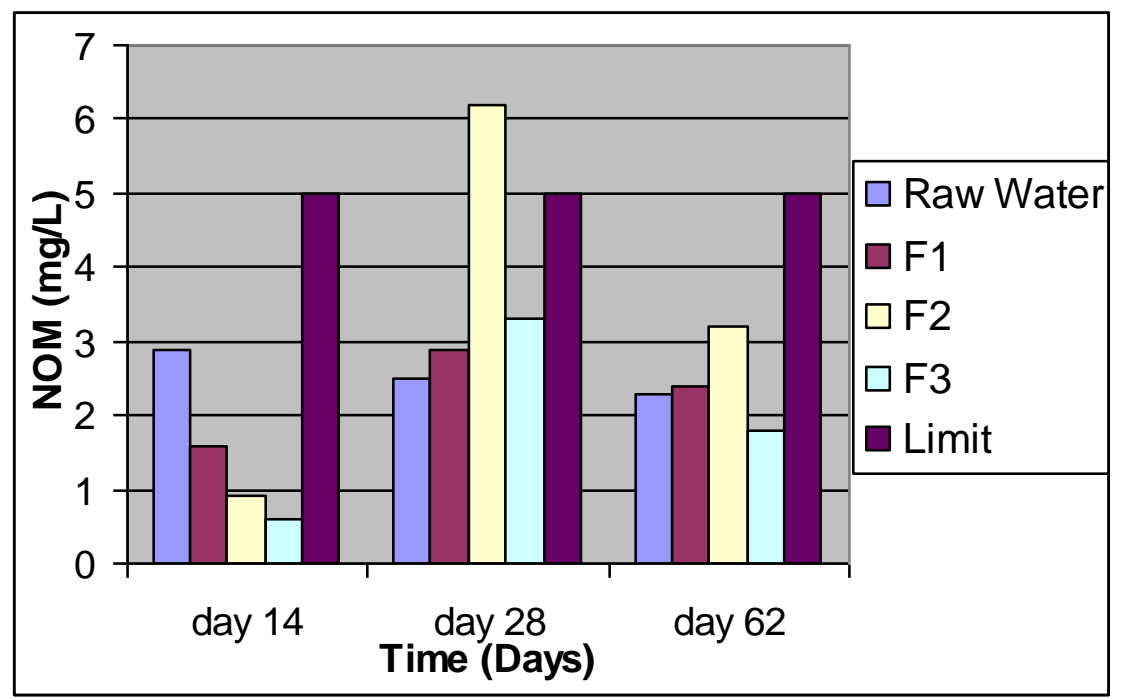

The high value produced by F2 at Day 28 shows that the traditional BSF occasionally produced poor effluent water quality, with high amounts of NOM after a few weeks of operation. This value was above the acceptable limit ( $>5 \mathrm{mg} / \mathrm{L}$ ) of water destined for human consumption, according to the French norm, AFNOR, and WHO standards. Cleaning was suggested to remove NOM such that just the right amount to support bacteria growth is retained; hence, better results were obtained during the eighth week. Since fractions of NOM are biodegradable, NOM may promote bacterial growth in the biofilm of the BSF, boosting bacterial population. In addition to NOM removal by microbial organisms in the schmutzdecke, it is probable that ZVI in F3 also removed organic material, such as humic acid, because trivalent metal ions $\left(\mathrm{Al}^{3+}\right.$ or $\left.\mathrm{Fe}^{3+}\right)$, and their hydroxide species $\left(\mathrm{Fe}(\mathrm{OH})_{\mathrm{n}}{ }^{3-\mathrm{n}}\right)$, will form insoluble complexes with NOM that will precipitate. That process is called charge neutralization [26]. This dual process may account for the high efficiency in the removal of NOM in F3.

Interestingly, F1 and the improved BSF (F3) both produced effluents with acceptable levels of NOM (i.e., $<5.0 \mathrm{mg} / \mathrm{L}$ ) in the drinking water throughout the experiment, according to the French Norm, AFNOR NF T90-420, of Cameroon drinking water standards and to WHO guidelines for drinking-water quality. However, the traditional BSF (F2) failed during the fourth week of operation. Ferric salts are common coagulants and studies [27,28] have shown that NOMs, such as humic acid, adsorb to iron oxides. Thus, it may be surmised that as contaminated water flows through the iron column, iron oxides are continuously formed, acting as binding sites for humic acid. The overall effect is the continuous removal of humic materials from contaminated water.

\subsection{Some Impacts on Water Chemistry}

The $\mathrm{pH}$ of raw water samples were measured daily, and the $\mathrm{pH}$ ranged from 7.5 to 8 . These values were maintained for the filtrate water samples, except for that of $\mathrm{F} 3$. The mean $\mathrm{pH}$ values recorded for the three experiments were; $\mathrm{F} 1=7.5, \mathrm{~F} 2=7.5$, and F3 $=6.5$. These values are within the $\mathrm{pH}$ range for drinking water in Cameroon, according to Norm AFNOR. Also, the amount of dissolved iron in water 
ranged from $0.0 \mathrm{mg} / \mathrm{L}$ to $0.4 \mathrm{mg} / \mathrm{L}$ (Table 6), with an average amount of $0.13 \mathrm{mg} / \mathrm{L}$ throughout the course of the filter experiments. The limit is $<0.2 \mathrm{mg} / \mathrm{L}$ for water destined for human consumption, according to the French Norm AFNOR.

Table 6. Amount of dissolved iron in F3 water samples over the course of the filter experiment.

\begin{tabular}{ccccc}
\hline Days & $\mathbf{1 4}$ & $\mathbf{2 8}$ & $\mathbf{6 2}$ & Limit \\
\hline F3 & 0.4 & 0.0 & 0.0 & $<0.2 \mathrm{mg} / \mathrm{L}$ \\
\hline
\end{tabular}

This suggests that there is a chemical reaction between iron and water, and supports the findings of You et al. [15] that there is continuous formation of complexes by the reaction of iron (oxyhydr)oxides, which serve as new adsorption sites for pathogens and NOM. The complexes formed settle out of solution and precipitate, and then remain within the filter bed.

\subsection{Head-Loss Development over BSF Operating Time}

The flow rates for the challenge filtration experiments are shown in Table 7, and the average flow rate is low for the traditional BSF (F2), but high for the Improved BSF (F3), and higher for F1.

Table 7. Daily Filtration (flow) Rate Upon initial 20 L Charge of Water over the course of the filtration experiment.

\begin{tabular}{|c|c|c|c|}
\hline & \multicolumn{3}{|c|}{ Flow rates (L/m) } \\
\hline Time (days) & F1 & F2 & F3 \\
\hline 1 & 2.1 & 1.2 & 1.9 \\
\hline 14 & 2 & 1.1 & 1.8 \\
\hline 22 & 1.95 & 0.9 & 1.8 \\
\hline 28 & 1.9 & 0.8 & 1.7 \\
\hline 32 & 1.8 & 0.8 & 1.5 \\
\hline 48 & 1.8 & 0.7 & 1.5 \\
\hline 54 & 1.8 & 0.6 & 1.5 \\
\hline 62 & 1.75 & 0.5 & 1.45 \\
\hline Average & $\mathbf{1 . 8 8 7 5}$ & $\mathbf{0 . 8 2 5}$ & $\mathbf{1 . 6 4 3 7 5}$ \\
\hline
\end{tabular}

The patterns of flow rate decline, and thus head-loss development, after each $20 \mathrm{~L}$ charge are compared for the three filter experiments as shown in Figure 4.

A decline in flow rate is expected due to head-loss accumulation as the filter ripens or matures. Particulate accumulation and biological growth in the top-most layer of the media bed are typically responsible for ripening. Figure 4 shows that higher flow rates were reported for F1 and F3, and they showed less of a decline in flow rates than did F2. The ZVI in F3 may have filled the pores of the large sand particles at the lower section of the media bed, reducing the flow of water through the pores in this section of the media bed; this may explain the difference in flow rates between F3 and F1, even though they have the same media ES. The concentration of organic substrate that supports the microbial colonization on the filter, which produces the head-loss, is a factor that was constant among 
the three filter experiments, because the concentrations of organic substrate in the $20 \mathrm{~L}$ charge were the same. Therefore, the results suggest that ripening and biofilm development will vary with the ES of media and flow rate. The increase in flow at Day 48 was due to the cleaning of the BSF; this gave a sharp increase in F2, but no sharp increase in F1 and F3, because solids in the raw water are able to penetrate deeper into the coarser sand, which have proportionately higher flow rate than fine sand with lower flow rate.

Figure 4. Filtration rate upon initial $20 \mathrm{~L}$ charge of water over the course of three filter microbial challenge experiments.

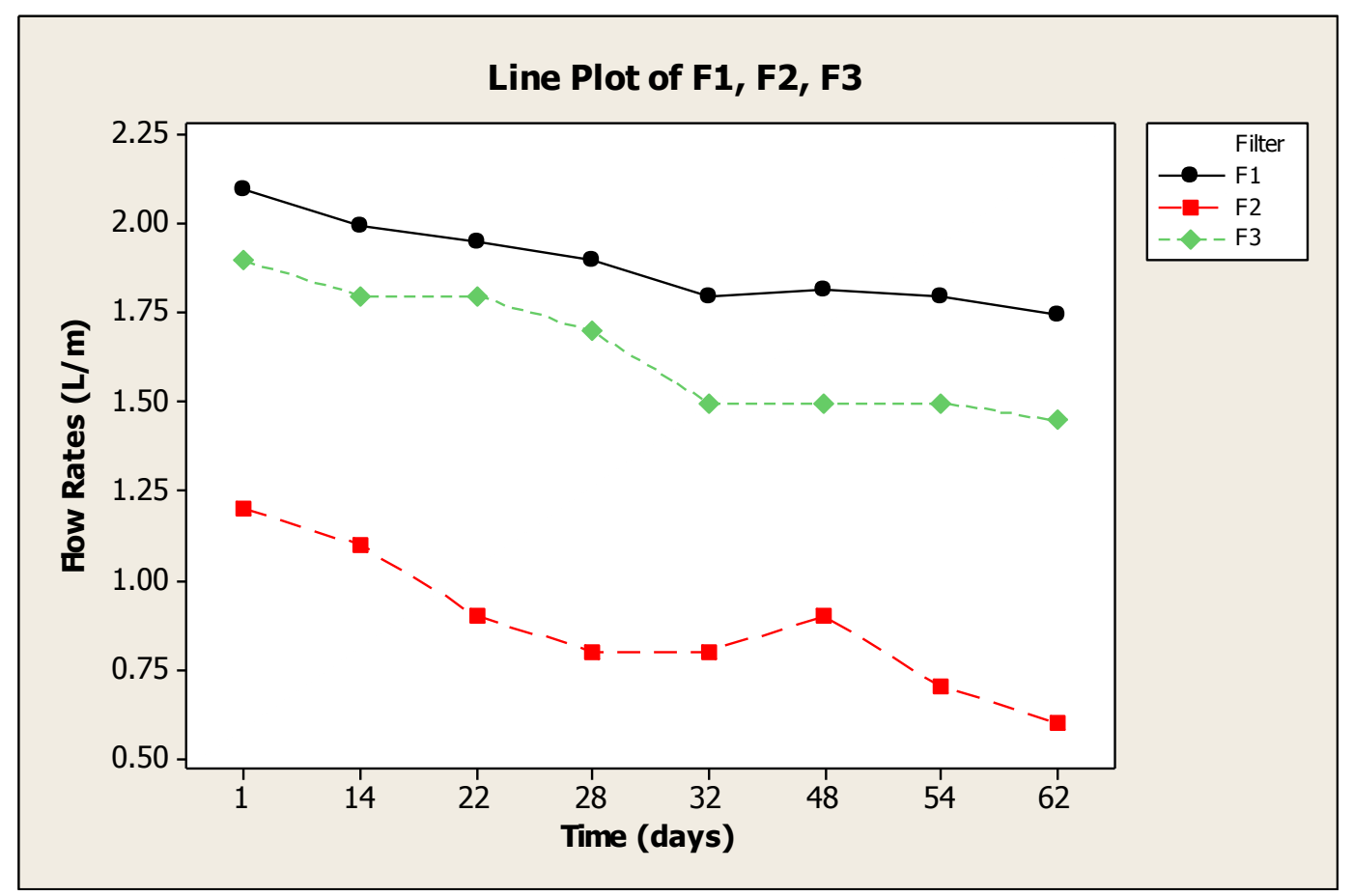

The mean flow rates for $\mathrm{F} 1, \mathrm{~F} 2$, and $\mathrm{F} 3$ were $1.9,0.8$, and $1.6(\mathrm{~L} / \mathrm{m})$, respectively, and this shows that the conventional flow rate of the traditional BSF (i.e., 0.6-1 L/m) can be increased considerably, while still providing safe water, if an effective disinfection stage is incorporated into the BSF. This will go a long way towards reducing the unnecessary waits. One often sees this predicament with users of traditional BSF who have large families. These people have to wait for longer periods, due to lower flow rates, to obtain enough filtered water to satiate the whole family.

Moreover, Baumgartner et al. [29] investigated the performance of the BSF with respect to pause times between filtration runs, water-dosing volumes, and the effluent volume at which a filtered water sample was collected. They found that total coliform removal by the BSF decreased with an increase in the sample collection volume; greater removal of total coliforms occurred when filter pause period was 12 hours versus 36 hours. The authors' findings encourage users to filter five liters of water at a time, or when filtering more than five liters at a time, to use the first five liters for drinking/cooking, and the remainder for other household needs. However, the results from this study suggest that users of the improved biosand filter will not have to rely on pause periods (though they are required), and can use more than five liters of water at a time for drinking. 


\subsection{Turbidity Removal}

Table 8 shows the percent removal of turbidity by the three filter experiments. The variation in turbidity removal is especially interesting, because it may offer some insight into the removal of inorganic particulate matter, such as clay or mud. Raw water turbidity averaged from 6 to 8 Nephelometric turbidity units (NTU), and filtered water turbidity ranged from 0.5 to 3 NTU.

Table 8. Percentage turbidity removal from raw water for the three filter experiments.

\begin{tabular}{|c|c|c|c|}
\hline Time (Days) & \multicolumn{3}{|c|}{ Turbidity Removal (\%) } \\
\hline & F1 & F2 & F3 \\
\hline 8 & 50 & 83.3 & 91.5 \\
\hline 25 & 51 & 95 & 95.1 \\
\hline 62 & 70 & 98 & 98 \\
\hline
\end{tabular}

The high raw water turbidity was seen during rainy periods and may be due to the runoff, which contains clay particles, entering into the well. After filtering raw water through the three filters F1, F2, and $\mathrm{F} 3$, the results show turbidity removals of up to $70 \%, 98 \%$, and $98 \%$ respectively, which not only attests to the small sizes of the colloids causing the turbidity, but also to the removal efficiency of BSF. A graphical display of percent turbidity removal over the course of three filter experiments is shown in Figure 5.

Figure 5. Average turbidity removal $(\%)$ over the course of the three filter experiments.

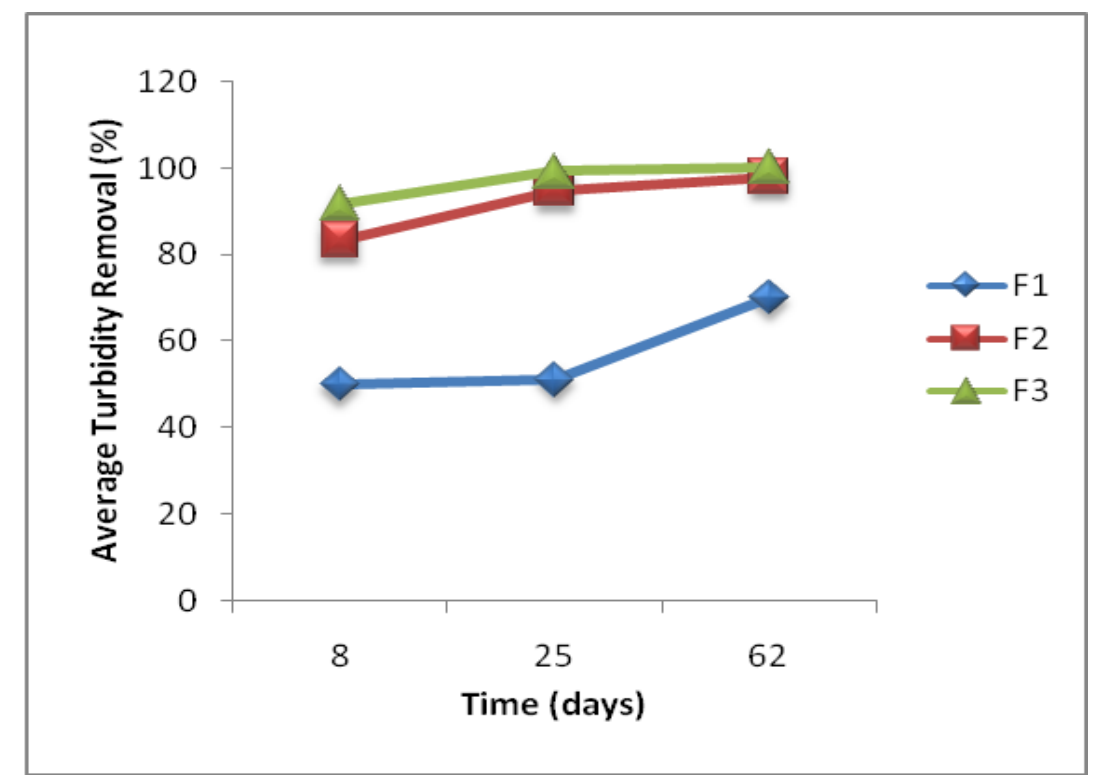

These results show the importance of biological action for the removal of inorganic and organic particles. The results show that turbidity removal improved as the biofilm ripened. Huisman and Wood [7] reported that the sticky gelatinous film on the surface of the schmutzdecke causes inert matter to be held until the schmutzdecke was removed. The production of exocellular polymers by the microorganisms attached to the sand particles within the sand bed also appears to be probable. Pavoni et al. [30] reported that exocellular polymers produced by activated-sludge-type bacteria could 
flocculate kaolinite (clay) suspensions and promote settling. It is suggested that the high turbidity removal observed in F2 could have been caused by high levels of production of exocellular polymer, while in F1 and F3, only a few exocellular polymers may have been produced. However, ferrous and ferric ions are common coagulants, and are speculated to have improved the effluent turbidity in F3, due to the ions' ability to coagulate suspended particles in the iron column.

\subsection{Taste and Odor Removal}

The effluent from the three filters showed improvement in the taste and odor of raw water; it is speculated that biodegradation of geosmin and MIB were dependent on the respiratory activity of the biofilter microorganisms. The degradation of geosmin and MIB, by bacteria attached to different filter media, have been utilized in the drinking water filtration processes, with extended retention times, such as slow sand filtration and infiltration [31-33]. Episodes of increased odor of raw water commonly occurred during the warm periods, when microbiological activity is high. Moreover, odor episodes occurred in F2, even when the raw water had no odor, when the effluent water measured high levels of NOM. This suggests that NOM is a possible cause of odor in water. However, the odor was absent after cleaning the BSF. Observed higher removals at higher influent concentrations of MIB by SSF have suggested the removal to behave almost as a first order reaction [34,35]. Based on the results of this study, the occurrence of odor in the BSF is said to be a signal for cleaning time. The precipitated insoluble complexes of the hydroxide species of iron with NOM in F3 did not give any odor problems, as the effluent water measured low levels of NOM.

\subsection{Effect of Sand Size on Bio-sand Filtration}

The results in Table 9 suggest that the treatment efficiency of the bio-sand filter is very sensitive to sand size.

Table 9. Effects of sand size on bio-sand filter performance.

\begin{tabular}{|c|c|c|c|c|c|c|c|}
\hline \multirow{2}{*}{ Filter } & \multirow{2}{*}{$\begin{array}{c}\text { Effective size } \\
\text { of sand (mm) }\end{array}$} & \multicolumn{3}{|c|}{$\begin{array}{c}\text { Average percent reduction } \\
\text { (\%) }\end{array}$} & \multirow{2}{*}{$\begin{array}{c}\text { Average } \\
\text { Turbidity } \\
\text { removal (\%) }\end{array}$} & $\begin{array}{c}\text { Average flow } \\
\text { rate (L/m) }\end{array}$ & $\begin{array}{c}\text { Average } \\
\text { NOM (\%) }\end{array}$ \\
\cline { 3 - 6 } & & TC & FC & FS & 98 & 0.82 & 53.97 \\
\hline F2 & 0.15 & 97.2 & 97.2 & 99 & 70 & 1.88 & 47.64 \\
\hline F1 & 0.3 & 31.7 & 31.7 & 98.9 & 70 \\
\hline
\end{tabular}

The average percentage reduction in pathogen indicators increased with decreasing sand size. It is suggested that mechanical processes, such as straining, changes in transport efficiency, and adsorption, may account for the $98.88 \%$ reduction in TC and FC in F2 at the start of the experiment. This would be expected, as the smaller interstices between smaller sand particles have a larger surface area, and would allow more adsorption to take place. In this light, the $31.7 \%$ reductions in TC and FC by the F1 experiment suggest inadequate purification when a larger ES of sand is used in the BSF, while the $97.2 \%$ reduction by $\mathrm{F} 2$ suggests a better result.

More so, it is suggested that FS was removed primarily by straining and by changes in transport efficiency, due to the fact that the smaller interstices between smaller sand particles in F2 may account 
for a $98.88 \%$ reduction of FS from the start of the experiments, while the larger interstices between larger sand particles in F1 may account for a 95\% reduction at the start of the experiment. However, to some extent, biofilm formation and straining, may account for the $98.57 \%$ reduction in F1 observed after eight weeks of filtration. This indicates that FS is physiologically different from FC and TC. The rate of flow in F1 and F3 is higher than that of F2, suggesting that the rate increases with an increase in sand size. Also, turbidity removal is greater in F2 than in F1, suggesting that the amount of removal increases with a decrease in the effective size of sand. Therefore, increases in the effective size of sand lead to decreases in microbial removal, turbidity removal, and NOM removal, and an increase in flow rate.

\section{Conclusions}

The improved household BSF, in which the zero-valent iron was incorporated, gave improved reductions in pathogens indicators, NOM, odor, and turbidity, relative to the performance of a traditional BSF. The flow rate increased with increases in sand size, while pathogen removal decreased with increases in sand size. The difference in the reduction for different microbes suggests multiple mechanisms of attenuation. The increase in microbial reduction that occurred over repeated charges and time in use is related to filter maturation and to the continuous formation of new adsorption sites (i.e., iron (oxyhdr)oxides). These mechanisms need a systematic study. These findings provide some answers to questions about the assurance of safe water provided to users via traditional BSF during the early stages of operation before biofilm formation. This was because the media had been modified to provide a disinfectant function to compensate for the lower initial microbial removal that was due to the lack of biofilm.

Removal of pathogen indicators was enhanced by the biocidal and coagulant effects of ZVI in the improved BSF (F3). Thus, ZVI has a high disinfection potential as a water treatment applicant in a household BSF, and therefore, ZVI can reduce chlorine use, which produces DBPs, such as trihalomethanes and haloacetic acids, through the reaction of chlorine with humic materials.

While acting as a disinfectant, ZVI also showed significant removal of NOM (e.g., humic acid). This provides an economical means of simultaneously reducing the risks associated with microbial pathogens, disinfectants, and DBPs.

Use of a larger media size can reduce the unnecessary waits for BSF users, so as to obtain larger volumes of filtered water in a short time, a capacity which is important for larger families. However, this necessitates the use of a disinfectant for the effective removal of microbial pathogens. Therefore, combining the increase in grain size of sand and the inclusion of ZVI as a supplemental filter medium can effectively counter the drawbacks of traditional BSF.

\section{Recommendations}

1. Since viruses are far smaller than bacteria and protozoan cysts, they can travel further into the sand bed of the BSF, thus making BSF less effective in removing viruses. Further research under well controlled conditions is needed to characterize viral removal by the improved BSF. 
2. Although this study indicates that the improved BSF can provide significant benefits, the capacity and limitations of ZVI use should be better understood, such as its long term performance and the quantity required in the BSF.

3. Further research is needed to better understand the mechanisms of adsorption and inactivation of microbial organisms and of the removal of NOM by ZVI.

\section{Acknowledgements}

The assistance of Peter Njodzeka of the Life and Water Development Group, Cameroon; Engineers Without Borders (EWB) of the University of Delaware (UD), USA; and Magda Pachocka of UD, USA have been very much appreciated.

Thanks are also expressed for support in data collection and analysis by the National Advanced School of Public Works (ENSTP) Yaoundé and the National Reference and Public Health Laboratory "Center Pasteur Du Cameroon."

\section{References}

1. Environmental priorities for development. In World Development Report: Development and the Environment; World Bank: Washington, DC, USA, 1992; pp. 44-50, 98-111.

2. Sobsey, M.; Stauber, C.; Casanova, L.; Brown, J.; Elliot, M. Point of use household drinking water filtration: A practical, effective solution for providing sustained access to safe drinking water in the developing world. Environ. Sci. Technol. 2008, 42, 4261-4267.

3. Elliott, M.A.; Stauber, C.E.; Koksal, F.; DiGiano, F.A.; Sobsey, M.D. Reductions of E. coli, echovirus type 12 and bacteriophages in a biosand filter. Water Res. 2008, 42, 2662-2670.

4. Ellis, K.V. Slow Sand Filtration. CRC Crit. Rev. Environ. Contr. 1985, 15, 315-354.

5. Ellis, K.V. Slow sand filtration. Water Engineering Development Center (WEDC). J. Develop. World Water 1987, 2, 196-198.

6. Slow Sand Filtration; Final Project Report; National Environmental Engineering Research Institute: Nagpur, India, 1977.

7. Huisman, L.; Wood, W.E. Slow Sand Filtration; World Health Organization: Geneva, Switzerland, 1974; pp. 47-79.

8. Biosand Filter. Manual for Design, Construction, Installation and Maintenance; Center for Affordable Water and Sanitation Technology (CAWST): Calgary, Canada, 2008; pp 26-79; Available online: http://www.CAWST.org (accessed on 1 June 2009).

9. Poynter, S.F.B.; Slade J.S. The removal of viruses by slow sand filtration. Prog. Water Technol. 1977, 9, 75-88.

10. Muhammad, N.; Ellis, K.; Parr, J.; Smith, M.D. Optimization of slow sand filtration. In Reaching the Unreached: Challenges for the 21st Century, Proceedings of the 22nd WEDC Conference, New Delhi, India, 9-13 September 1996.

11. Jin, Y.; Chu, Y.; Li, Y. Virus removal and transport in saturated and unsaturated sand columns. J. Contam. Hydrol. 2000, 43, 111-128. 
12. Stauber, C.E.; Elliott, M.A.; Koksal, F.; Oritz, G.M.; Digiano, F.A.; Sobsey, M.D. Characterization of the biosand filter for E. coli reductions from household drinking water under controlled laboratory conditions and field use conditions. Water Sci. Technol. 2006, 54, 1-7.

13. Anders, R.; Chrysikopoulos, C. Transport of viruses through saturated and unsaturated columns packed with sand. Trans. Porous Media 2009, 76, 121-138.

14. Changha, L.; Kim, J.Y.; Won, I.L.; Kara, L.N.; Jeyong, Y.; David, L.S. Bacteriocidal effect of zero-valent iron nanoparticles on Escherichia coli. Environ. Sci. Technol. 2008, 42, 4927-4933.

15. You, Y.; Han, J.; Chiu, P.; Jin, Y. Removal and inactivation of waterborne viruses using zero-valent iron. Environ. Sci. Technol. 2005, 39, 9263-9269.

16. Rao, D.R.J. Evolving high rate filter and use of crushed stone as filter media. J. Inst. Eng. 1981, 61, 92-96.

17. Elliott, M.A.; Stauber, C.E.; KoKsal, F.; Liang, K.R.; Huslage, D.K.; Digiano, F.A.; Sobsey, M.D. The operation, flow conditions and microbial reductions of an intermittently operated, household-scale slow sand filter. In Recent Progress in Slow Sand and Alternative Biofiltration Processes; Gimbel, R., Graham, N.J.D., Collins, M.R., Eds.; International Water Association: London, UK, 2006.

18. Guidelines for Drinking-Water Quality; First addendum to third edition, Volume 1 Recommendations; WHO: Geneva, Switzerland, 2006.

19. Nam, T.K.; Timmons, M.B.; Montemagno, C.D.; Tsukuda, S.M. Biofilm characteristics as affected by sand size and location in fluidize bed vessels. Aquacult. Eng. 2000, 22, 346-349.

20. Chiu, P. New Technology removes viruses from drinking water. University of Delaware Daily (UDaily) Archive, 2007; Available online: http://www.udel.edu/PR/UDaily/2007/feb/viruses 022607.html (accessed on 19 February 2009).

21. Murray, J.P.; Laband, D.J. Degradation of poliovirus by adsorption on inorganic surfaces. Appl. Environ. Microbiol. 1979, 37, 480-486.

22. Moore, E.S.; Tylor, D.H.; Sturman, L.S.; Reddy, M.M. Poliovirus adsorption by 34 minerals and soils. Appl. Environ. Microbiol. 1981, 42, 963-975.

23. Zhuang, J.; Jin, Y. Effects of $\mathrm{pH}$ and phosphate on virus interaction with oxides. Water Sci. Technol. 2009, (in press).

24. Collins, M.R.; Eighmy, J. M.; Fenstermacher J.; Spanos S.K. Removing natural organic matter by conventional slow sand filtration. J. Am. Water Works Assoc. 1992, 84, 80-90.

25. Weiss, W.J.; Bouwer, E.J.; Ball, W.P.; O’Melia, C.R.; Aboytes, R.; Speth, T.F. Riverbank filtration: Effect of ground passage on NOM character. J. Water Supply Res. Technol.-Aqua 2004, 53, 61-83.

26. Frank, P. Biofilms in Drinking Water Treatment-Biofiltration, Membrane Fouling and Regrowth Potential; Medicinaregatan 20A: Göteborg, Sweden, 2005, (unpublished work).

27. Gu, B.; Phelps, T.J.; Liang, L.; Dickey, M.J.; Roh, Y.; Kinsall, B.L.; Palumbo, A.V.; Jacobs, A.V. Biochemical dynamics in elemental iron columns: Implications for permeable reactive barriers. Environ. Sci. Technol. 1994, 33, 2170-2177.

28. Dries, J.; Bastiaen, L.; Springael, D.; Agathos, S.N.; Diels, L. Competition for sorption and degradation of chlorinated ethenes in batch zero-valent iron system. Environ. Sci. Technol. 2004, $38,2879-2884$. 
29. Baumgartner, J.; Murcott, S.; Majid, E. Effects of operating conditions on the bacterial removal of two household drinking-water filters. Environ. Res. Lett. 2007, 32, 12-56.

30. Pavoni, J.L.; Tenny, M.W.; Echelberger, W.F. Bacterial Exocellular Polymers and Biological Flocculation. J. WPCF 1972, 44, 3-414.

31. Jüttner, F. Elimination of terpenoid odorous compounds by slow sand filtration and river bank filtration of the Ruhr River, Germany. Water Sci. Technol. 1995, 31, 211-227.

32. Sävenhed, R.; Borén, H.; Grimvall, A.; Lundgren, B.V.; Balmér, P.; Hedberg, T. Removal of individual off-flavor compounds in water during artificial groundwater recharge and during treatment by alum coagulation/sand filtration. Water Res. 1987, 21, 277-283.

33. Yagi, M.; Kajino, M.; Matsuo, U.; Ashitani, K.; Kita, T.; Nakamura, T. Odor problems in lake Biwa. Water Sci. Technol. 1983, 15, 311-321.

34. Egashira, K.; Ito, K.; Yoshiy, Y. Removal of musty odor compound in drinking water by biological filter. Water Sci. Technol. 1992, 25, 307-314.

35. Terauchi, N.; Ohtani, T.; Yamanaka, K.; Tsuji, T.; Sudou, T.; Ito, K. Studies on a biological filter for musty odor removal in drinking water treatment processes. Water Sci. Technol. 1995, 31, 229-235.

(C) 2010 by the authors; licensee MDPI, Basel, Switzerland. This article is an Open Access article distributed under the terms and conditions of the Creative Commons Attribution license (http://creativecommons.org/licenses/by/3.0/). 